\title{
Comparison of the efficacy of QoI fungicides, alone or in mixture with triazoles, in Asian soybean rust control, 2016/17 growing season
}

\author{
Erlei Melo Reis ${ }^{1}$, Luis Henrique Carregal ${ }^{2}$, Mateus Zanatta ${ }^{3}$
}

\begin{abstract}
${ }^{1}$ Facultad de Agronomia, Universidad de Buenos Aires, Av. San Martín 4453, C1417DSE, Argentina; ${ }^{2}$ Agrocarregal, Av. Pres. Vargas. Condomínio Centro Empresarial Le Monde., 266, sala 401, 4 andar, Setor Jardim Marconal, Rio Verde, CEP 75.901-551, Goiás - GO, Brasil; ${ }^{3}$ Agroservice, Rua Miguel Vargas, 291, CEP 99035-380, Passo Fundo, RS, Brasil.
\end{abstract}

Autor para correspondência: Erlei Melo Reis (erleireis@upf.br).

Data de chegada: 15/01/2018. Aceito para publicação em: 15/07/2018.

$10.1590 / 0100-5405 / 190157$

\section{ABSTRACT}

Reis, E.M.; Carregal, L.H.; Zanatta, M. Comparison of the efficacy of QoI fungicides, alone or in mixture with triazoles, in Asian soybean rust control, 2016/17 growing season. Summa Phytopathologica, v.45, n.2, p.28-32, 2019.

Evolution has been reported for the reduction in Phakopsora pachyrhizi sensitivity to the mixtures of the three site-specific mechanisms of action (DMIs, QoIs and SDHIs) used in its control. The aim of this study was to quantify the current contribution of QoIs, alone or in mixture with triazoles, in the control of Asian soybean rust. In an experiment carried out in the field, the efficacy of quinone outside inhibitors (QoIs), or strobilurins, was compared for Asian soybean rust control. The isolated effects of four doses of azoxystrobin, picoxystrobin, pyraclostrobin and trifloxystrobin were evaluated, as well as of four applications during the crop cycle. Control by commercial mixtures of these QoIs with triazoles was also compared. Severity was evaluated in four phenological stages, and control was calculated based on final severity data, area under rust progress curve, defoliation, one-thousand-grain mass, grain yield and damage caused by the disease. The lowest mean of rust control efficacy resulted from applications of azoxystrobin (15.8 and $11.19 \%$ ) and pyraclostrobin (15.4 and 16.76\%) and the highest mean was found for picoxystrobin (54.1 and $54.35 \%)$ and trifloxystrobin (69.7 and 64.46\%), calculated based on final severity and AUDPC, respectively. Such efficacy is not enough to cover the fungicide application cost, although there was a positive effect of treatments on disease control and grain yield.

Keywords: quinone outside inhibitors, sensitivity reduction, Phakopsora pachyrhizi, resistance to fungicides.

\section{RESUMO}

Reis, E.M.; Carregal, L.H.; Zanatta, M. Comparação da eficácia de fungicidas IQes, isolados ou em mistura com triazóis, no controle da ferrugem asiática da soja, safra 2016/17. Summa Phytopathologica, v.45, n.2, p.28-32, 2019.

Tem sido relatada a evolução da redução da sensibilidade de Phakopsora pachyrhizi às misturas dos três mecanismos de ação sítio-específicos (IDMs, IQes e ISDHs) usadas no seu controle. O objetivo desse trabalho foi quantificar a contribuição atual dos IQes, isolados ou em mistura com triazpois, no controle da ferrugem asiática da soja. Em experimento conduzido no campo comparouse a eficácia dos inibidores da quinona externa (IQes), ou estrobilurinas, no controle da ferrugem da soja. Foram avaliados os efeitos isolados de quatro doses da azoxistrobina, picoxistrobina, piraclostrobina e trifloxistrobina e de quatro aplicações durante o ciclo da cultura. Comparou-se também o controle das misturas comerciais desses IQes com triazóis. Avaliou-se a severidade em quatro estádios fenológicos, calculou-se o controle com dados da severidade final, com dados da área abaixo da curva de progresso da ferrugem, a desfolha, a massa de mil grãos, o rendimento de grãos e o dano causado pela doença. A menor eficácia média no controle da ferrugem resultou das aplicações da azoxistrobina ( 15,8 e $11,19 \%)$ e da piraclostrobina $(15,4$ e $16,76 \%)$ e a maior para a picoxistrobina $(54,1$ e $54,35 \%)$ e trifloxistrobina $(69,7$ e $64,46 \%)$ calculada respectivamente com dados da severidade final e da AACPD. Essa eficácia não é suficiente para cobrir o custo da aplicação dos fungicidas, embora tenha sido observado reflexo positivo dos tratamentos no controle e no rendimento de grãos.

Palavras-chave: inibidores da quinona externa, redução da sensibilidade, Phakopsora pachyrhizi, resistência a fungicidas

The soybean [Glycine $\max ($ L.) Merr.] area cultivated in Brazil has been increasing every growing season. In 2016/17, it was 33.4 million hectares and in 2017/18 it was estimated at 35.33 million hectares (1).

Considering the diseases that affect soybean, the greatest damage is due to Asian soybean rust (ASR), caused by the Basidiomycete fungus Phakopsora pachyrhizi Sydow \& Sydow (16), which was detected in South America in 2001 (7). Damage to soybeans can be scientifically estimated based on the damage function $y=1,000-6.21 \mathrm{LI}$, where ' $y$ ' is the yield normalized to $1,000 \mathrm{~kg} / \mathrm{ha}$ and $\mathrm{LI}$ is the incidence in the central leaflets inserted in the main plant stem (2).

ASR control measures include sowing early maturing cultivars at the beginning of the recommended season, growing cultivars with partial resistance to rust, observing the soybean-free period, eliminating volunteer plants and applying fungicides in the foliage when the disease is detected in the region (13).

Chemical control of ASR began in the 2002/03 season (4). Differently from FRAC's recommendations (3), site-specific DMI fungicides (difenoconazole, flutriafol, tebuconazole) have been used alone, resulting in over $80 \%$ control (8).

From the 2005/06 season, based on producers' complaints of control failure and on scientific reports $(8,15)$, double mixtures of site-specific fungicides DMIs + QoIs (azoxystrobin + cyproconazole and pyraclostrobin + epoxiconazole), endorsed by FRAC (3) as an anti-resistance strategy, started to be used. However, in the 20012/13 
season, producers complained again of control failure regarding these site-specific co-formulations (9).

In the 2014/15 soybean crop, ASR control was done by spraying fungicide mixture containing SDHI (benzovindiflupyr + azoxystrobin), which had an efficiency greater than $90 \%$. After three seasons of use, data from experimental fields showed reduced control by this mixture (9). Therefore, in 16 years, the three site-specific fungicides became inefficient in controlling ASR in Brazil. Moreover, DMIs and QoIs alone or in co-formulation with each other or with SDHIs showed a reduction in ASR control efficacy, indicating that double or triple mixtures do not work as an anti-resistance strategy.

In parallel to the reduction in $P$. pachyrhizi sensitivity to the three active ingredients (DMI, QoI and SDHI), the respective fungal mutations that confer cross and multiple resistance to the three mechanisms of action (MOA) were identified $(4,6,14)$.

We hypothesized that the fungitoxicity of the four QoIs currently in use against $P$. pachyrhizi, with the same mechanism of action, has differently reduced, resulting in differences in efficacy among them.

The aim of this study was to quantify the current contribution of QoIs, alone or in mixture with triazoles, to Asian soybean rust control.

\section{MATERIAL AND METHODS}

The experiment was carried out at Agrocarregal Experimental Station - AES, Rio Verde, Goiás State, Brazil, coordinates: longitude $17^{\circ} 47^{\prime} 1.4^{\prime \prime} \mathrm{S}$, latitude $51^{\circ} 00^{\prime} 37^{\prime \prime} \mathrm{W}$, at $790 \mathrm{~m}$ a.s.1. The effects of treatments were evaluated on soybean cultivar NS 7209, seeded on 12/14/2016, 16 seeds/m, under natural inoculation.

Four QoIs were compared in the commercial formulations: (i) azoxystrobin (Priori $250 \mathrm{SC}$ ) 240, 360 and $480 \mathrm{~mL} / \mathrm{ha}$; (ii) pyraclostrobin (Comet $250 \mathrm{CE}$ ) 240, 360 and $480 \mathrm{~mL} / \mathrm{ha}$, (iii) picoxystrobin (Oranis $250 \mathrm{SC}$ ) 240,360 and $480 \mathrm{ml} / \mathrm{ha}$, and (iv) trifloxystrobin (Flint 500 WG) 180,240 and $400 \mathrm{~g} / \mathrm{ha}$. As additional treatments, the performance of the mixtures azoxystrobin + cyproconazole (Priori Xtra $300 \mathrm{~mL} / \mathrm{ha}$ ), pyraclostrobin + fluxapyroxad (Orkestra $300 \mathrm{ml} / \mathrm{ha}$ ), picoxystrobin + cyproconazole (Aproach Prima $300 \mathrm{~mL} / \mathrm{ha}$ ), and trifloxystrobin + prothioconazole (Fox $400 \mathrm{~mL} / \mathrm{ha}$ ) were compared. The recommended oil was added to each fungicide.

The fungicides were sprayed four times with a $\mathrm{CO}_{2}$ pressurized precision sprayer and 150L/ha volume: (i) on 01/30/2017, at V6 growing stage; (ii) on $02 / 14 / 2017$, at R5.1; (iii) on $02 / 28 / 2017$, at R5.4, and (iv) on $13 / 03 / 2017$ at R5.5.

Experimental design was in completely randomized blocks with four replicates and experimental units of $2.25 \times 6.00 \mathrm{~m}$ long; data were analyzed according to Scott-Knott test.

ASR severity, based on the percentage of leaf area covered with symptoms/signs, was evaluated on 3/6/2017 (GS R5.3), 03/11/2017 (R5.4), 03/19/2017 (R6) and 03/23/2017 (R6), which was used to calculate the area under disease progress curve (AUDPC). Defoliation $(\%)$, one-thousand-grain mass $(\mathrm{g})$ and grain yield were also evaluated.

\section{RESULTS AND DISCUSSION}

Table 1. Effect of treatments on rust severity, area under the disease progress curve (AUDPC), and disease control.

\begin{tabular}{|c|c|c|c|c|}
\hline Treatment & Severity (\%) & $\begin{array}{c}\text { Control }(\%) \text { in relation } \\
\text { to severity }\end{array}$ & AUDPC & $\begin{array}{c}\text { Control (\%) in relation } \\
\text { to AUDPC }\end{array}$ \\
\hline 1- Unsprayed & $75.00 \mathrm{i}$ & - & $1216.37 \mathrm{~h}$ & - \\
\hline 2- Azoxystrobin & $66.25 \mathrm{~h}$ & 11.7 & $1033.62 \mathrm{~g}$ & 15.02 \\
\hline 3- Azoxystrobin & $66.25 \mathrm{~h}$ & 11.7 & $1043.75 \mathrm{~g}$ & 14.19 \\
\hline 4- Azoxystrobin & $57.00 \mathrm{f}$ & 24.0 & $992.87 \mathrm{f}$ & 18.37 \\
\hline Mean azoxystrobin & 63.17 & 15.8 & 1023.41 & 11.19 \\
\hline 5- Azoxystrobin + cyproconazole & $41.75 \mathrm{e}$ & 44.3 & $656.00 \mathrm{e}$ & 46.07 \\
\hline 6- Pyraclostrobin & $63.00 \mathrm{~g}$ & 16.0 & $1023.37 \mathrm{~g}$ & 15.87 \\
\hline 7- Pyraclostrobin & $66.75 \mathrm{~h}$ & 11.0 & $1035.25 \mathrm{~g}$ & 14.89 \\
\hline 8- Pyraclostrobin & $60.50 \mathrm{~g}$ & 19.3 & $976.62 \mathrm{f}$ & 19.71 \\
\hline Mean pyraclostrobin & 63.41 & 15.4 & 704.74 & 16.76 \\
\hline 9- Pyraclostrobin + fluxapyroxad & $21.37 \mathrm{~b}$ & 71.5 & $381.62 \mathrm{~b}$ & 68.63 \\
\hline 10- Picoxystrobin & $39.25 \mathrm{e}$ & 47.7 & $671.75 \mathrm{e}$ & 44.77 \\
\hline 11- Picoxystrobin & $31.00 \mathrm{~d}$ & 58.7 & $481.87 \mathrm{~d}$ & 60.38 \\
\hline 12- Picoxystrobin & $33.00 \mathrm{~d}$ & 56.0 & $512.12 \mathrm{~d}$ & 57.9 \\
\hline Mean picoxystrobin & 34.41 & 54.1 & 552.24 & 54.35 \\
\hline 13- Picoxystrobin + cyproconazole & $24.75 \mathrm{c}$ & 67.0 & $370.50 \mathrm{~b}$ & 69.54 \\
\hline 14- Trifloxystrobin & $23.25 \mathrm{c}$ & 69.0 & $448.50 \mathrm{c}$ & 63.13 \\
\hline 15- Trifloxystrobin & $20.25 \mathrm{~b}$ & 73.0 & $387.37 \mathrm{~b}$ & 68.15 \\
\hline 16- Trifloxystrobin & $24.50 \mathrm{c}$ & 67.3 & $424.25 \mathrm{c}$ & 65.12 \\
\hline Mean trifloxystrobin & 22.66 & 69.7 & 420.04 & 64.46 \\
\hline 17- Trifloxystrobin + prothioconazole & $15.50 \mathrm{a}$ & 79.3 & $291.12 \mathrm{a}$ & 76.07 \\
\hline C.V. & 4.95 & - & 3.14 & - \\
\hline
\end{tabular}

Means followed by the same letter in each column did not differ statistically from one another according to Scott-Knott test at 5\%. 
ASR was detected in the experimental area on March $7^{\text {th }}, 2017$, and within 41 days the severity progressed from 0 to $100 \%$ (data not shown).

Severity was $75 \%$ in unsprayed plots, and $63.1 \%$ for azoxystrobin, $63.4 \%$ for pyraclostrobin, $34.4 \%$ for picoxystrobin, $22.6 \%$ for trifloxystrobin and $15.50 \%$ for trifloxystrobin + prothioconazole (Table 1).

ASR control was calculated based on the data from the third severity assessment and from AUDPC. As to severity, the efficacy of treatments ranged from $11.0 \%$ (pyraclostrobin $360 \mathrm{~mL} / \mathrm{ha}$ ) to $73 \%$ (trifloxystrobin $240 \mathrm{~mL} / \mathrm{ha}$ ). When calculated by using AUDPC, the control efficacy varied from $14.8 \%$ (pyraclostrobin $360 \mathrm{~mL} / \mathrm{ha}$ ) to $68.1 \%$ (trifloxystrobin $240 \mathrm{~mL} / \mathrm{ha}$ ). Considering QoI mixed with DMIs, when calculated based on severity, the efficacy ranged from 44.3 for azoxystrobin + cyproconazole, 71.5 for pyraclostrobin + fluxapyroxad to 79.3 for trifloxystrobin + prothioconazole, respectively. Similarly to the calculation based on AUDPC data, the control efficacy was 46.0, 68.3 and $76.0 \%$, respectively (Table 1 ).

If not transformed into efficacy, the values for AUDPC make comparisons difficult among treatments. In the unsprayed plots, the highest value was 1216.37 and the lowest one was 291.1 units, only allowing the identification of the best treatment. However, when expressed as control, such difficulty was eliminated. For example, the maximum control of $76.0 \%$, close to $80 \%$, is considered the minimum to match the fungicide spraying cost in order to control ASR (11).

Defoliation of soybean plants ranged from $77.25 \%$ to $100 \%$ and was a function of ASR intensity (Table 2).

Regarding one-thousand-grain mass, the lowest value was $129.7 \mathrm{~g}$, determined for grains of the unsprayed plots, while the highest value was $162.9 \mathrm{~g}$ for grains from plots that were sprayed with pyraclostrobin + fluxapyroxad (Table 2). Data regarding one-thousand-grain mass, as well as AUDPC, have little importance in the selection of treatments with greater efficacy for disease control.

Grain yield in the unsprayed plots was $2508 \mathrm{~kg} / \mathrm{ha}$ and, in the best treatment (pyraclostrobin + fluxapyroxad), it was $3579 \mathrm{~kg} / \mathrm{ha}$, corresponding to a maximum damage of $1071.6 \mathrm{~kg} / \mathrm{ha}$ or $29.9 \%$. The average yield of sprayed plots was $2528.9 \mathrm{~kg} / \mathrm{ha}, 2613.8 \mathrm{~kg} / \mathrm{ha}$ for pyraclostrobin, $2991.6 \mathrm{~kg} / \mathrm{ha}$ for picoxystrobin, and $3110.4 \mathrm{~kg} / \mathrm{ha}$ for trifloxystrobin.

Defoliation of soybean plants was a positive and linear function of ASR severity expressed as the function $y=0.4729 x+68.815$, with coefficient of correlation, $\mathrm{R}^{2}=0.8316$, where ' $\mathrm{y}$ ' is plant defoliation and ' $\mathrm{X}$ ' is rust severity (Fig. 1). The equation indicates that every $1 \%$ rust severity caused $0.4729 \%$ defoliation. The report by Reis et al.

Table 2. Effect of treatments on the defoliation of soybean plants, one-thousand-grain weight $(\mathrm{GW})$, and grain yield.

\begin{tabular}{|c|c|c|c|}
\hline Treatment & Defoliation (\%) & GW (g) & Grain Yield (kg/ha) \\
\hline 1- Unsprayed & $100.00 \mathrm{~h}$ & $129.76 \mathrm{e}$ & $2508.13 \mathrm{c}$ \\
\hline 2- Azoxystrobin & $98.75 \mathrm{~h}$ & $131.52 \mathrm{e}$ & $2561.63 \mathrm{c}$ \\
\hline 3- Azoxystrobin & $99.50 \mathrm{~h}$ & $134.93 \mathrm{e}$ & $2486.43 \mathrm{c}$ \\
\hline 4- Azoxystrobin & $100.00 \mathrm{~h}$ & $133.08 \mathrm{e}$ & $2538.67 \mathrm{c}$ \\
\hline Mean azoxystrobin & - & - & 2528.91 \\
\hline 5- Azoxystrobin + cyproconazole & $90.25 \mathrm{~g}$ & $144.45 \mathrm{c}$ & $2957.42 \mathrm{~b}$ \\
\hline 6- Pyraclostrobin & $100.00 \mathrm{~h}$ & $132.81 \mathrm{e}$ & $2554.18 \mathrm{c}$ \\
\hline 7- Pyraclostrobin & $100.00 \mathrm{~h}$ & $136.34 \mathrm{e}$ & $2640.59 \mathrm{c}$ \\
\hline 8- Pyraclostrobin & $99.50 \mathrm{~h}$ & $131.19 \mathrm{e}$ & $2646.77 \mathrm{c}$ \\
\hline Mean pyraclostrobin & - & - & 2613.85 \\
\hline 9- Pyraclostrobin + fluxapyroxad & $66.75 \mathrm{a}$ & $162.96 \mathrm{a}$ & 3579.80 a \\
\hline 10- Picoxystrobin & $90.50 \mathrm{~g}$ & $141.51 \mathrm{~d}$ & $2965.04 \mathrm{~b}$ \\
\hline 11- Picoxystrobin & $83.00 \mathrm{e}$ & $141.46 \mathrm{~d}$ & $2976.29 \mathrm{~b}$ \\
\hline 12- Picoxystrobin & $80.75 \mathrm{~d}$ & $145.19 \mathrm{c}$ & $3032.92 \mathrm{~b}$ \\
\hline Mean picoxystrobin & - & - & 2991.62 \\
\hline 13- Picoxystrobin + cyproconazole & $79.25 \mathrm{c}$ & $154.42 \mathrm{~b}$ & $3368.95 \mathrm{a}$ \\
\hline 14- Trifloxystrobin & $88.50 \mathrm{~g}$ & $145.57 \mathrm{c}$ & $3003.86 \mathrm{~b}$ \\
\hline 15- Trifloxystrobin & $80.00 \mathrm{~d}$ & $147.95 \mathrm{c}$ & $3132.40 \mathrm{~b}$ \\
\hline 16- Trifloxystrobin & $80.75 \mathrm{~d}$ & $148.75 \mathrm{c}$ & $3195.23 \mathrm{~b}$ \\
\hline Mean trifloxystrobin & - & - & 3110.49 \\
\hline 17- Trifloxystrobin + prothioconazole & $77.25 \mathrm{~b}$ & $156.55 \mathrm{~b}$ & $3489.27 \mathrm{a}$ \\
\hline C.V. $(\%)$ & 1.23 & 2.83 & 6.55 \\
\hline
\end{tabular}

Means followed by the same letter in each column did not differ statistically from one another according to Scott-Knott test at $5 \%$. 


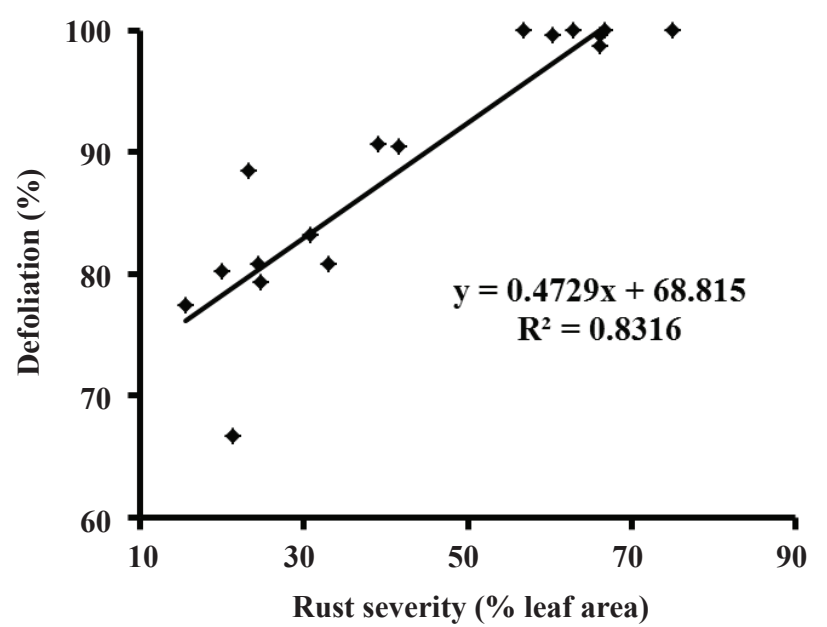

Figure 1. Positive relationship between foliar rust severity $(\mathrm{x})$ and soybean plant defoliation (y).

(10) confirms that defoliation is a function of ASR severity and that its evaluation is not necessary since severity data alone are sufficient to explain the effect of disease intensity on soybean yield, a reflex of the efficacy of treatments.

The relationship between grain yield and ASR severity was

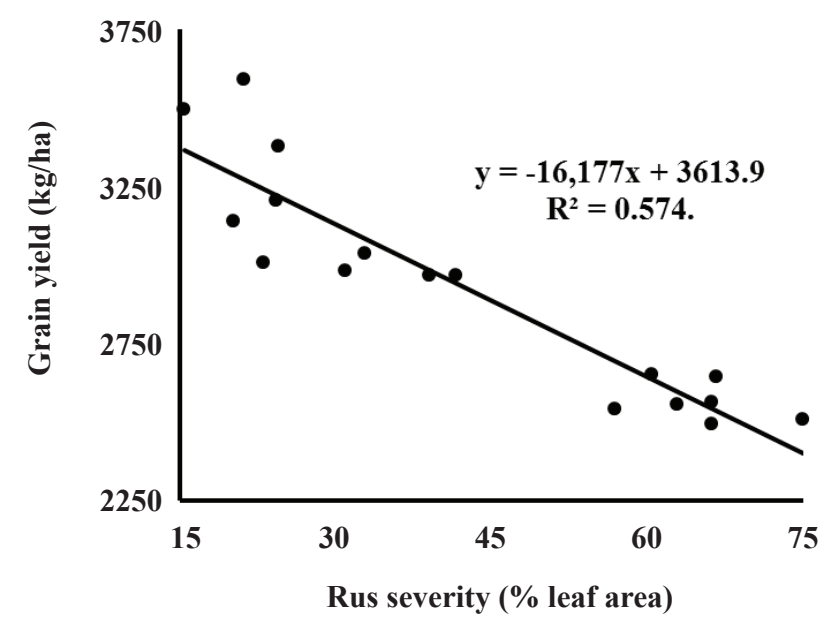

Figure 2. Negative relationship between grain yield (y) and Asian soybean rust severity $(\mathrm{x})$.

expressed as the function $y=-16.177 x+3613.9, R \cdot, \bullet \vee \varepsilon=2$, where ' $y$ ' is grain yield, ' $x$ ' is ASR severity, and $R$ is the coefficient of determination. According to the equation, every $1.0 \%$ severity reduces $16.177 \mathrm{~kg} /$ ha grains in $3613.9 \mathrm{~kg} /$ ha potential yield (Fig. 2).

Considering the AUDPC ratio of rust on grain yield, the obtained damage function was $y=-1.061 \mathrm{x}+3665.5$, R2 0.875 , where each unit of AUDPC reduced $1.061 \mathrm{~kg} / \mathrm{ha}$ in $3666.5 \mathrm{~kg} / \mathrm{ha}$ yield (Fig. 3). The AUDPC has been recommended especially for the evaluation of the reaction of cultivars to diseases, having no practical importance to estimate the damage caused by a disease in a crop (5). In this case, the determination and practical use of severity has an advantage over AUDPC, which is more time-consuming.

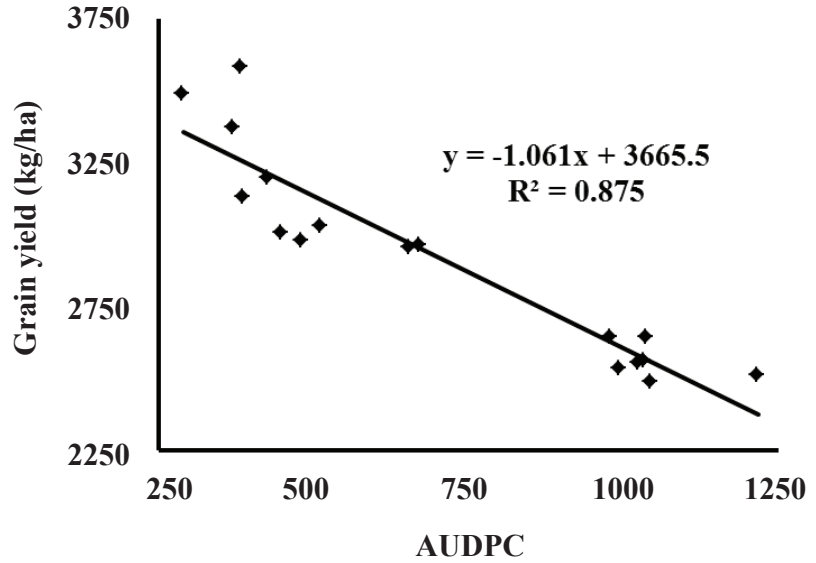

Figure 3. Negative relationship between soybean grain yield (y) and area under Asian soybean rust severity progress curve (AUDPC) (x).

Our results confirmed $(6,8,9,14)$ the low field performance of fungicides containing strobilurins in ASR control. After detection of the mutation at position F129L, which confers a reduction in P. pachyrhizi sensitivity to QoIs, studies have been carried out to quantify whether this mutation differently affected the fungitoxicity of the four strobilurins mostly used for ASR control. Although they have the same mechanism of action, inhibition of electron transfer in the respiratory chain of complex III in the mitochondria, their efficacy was different: one group showed $15.8 \%$ (azoxystrobin) and $15.4 \%$ (pyraclostrobin) control, and the other group had superior mean control, picoxystrobin $54.1 \%$ and trifloxystrobin $(69.7 \%)$ (Table 1).

Azoxystrobin + cyproconazole co-formulation, used in the 2009/10 season, was sprayed on 10 million ha in the 2006/07 season, and pyraclostrobin + epoxiconazole mixture in 15 million ha. Therefore, exposure to the fungus for a long time may have determined the most pronounced reduction in fungitoxicity to $P$. pachyrhizi; in addition, differences in the intrinsic characteristics of the molecules of QoIs can determine differences in fungitoxicity among them.

Finally, it can be inferred that the greater efficacy of picoxystrobin and trifloxystrobin explains the better performance of commercial mixtures of picoxystrobin + cyproconazole and trifloxystrobin + prothioconazole in ASR control. In contrast, the reduced fungitoxicity of azoxystrobin and pyraclostrobin explains the inferior performance of the mixtures in which they are incorporated.

\section{REFERENCES}

1. Conab - Companhia Nacional de Abastecimento, Grãos, safra 2016/17 12 levantamento, Setembro de 2017. Disponível em: http://www.conab.gov.br/conteudos.php?a=1253. Acesso em 25 de julho, 2017.

2. Danelli, A.L.D.; Reis, E.M.; Boaretto, C. Critical-point model to estimate yield loss caused by Asian soybean rust. Summa Phytopathologica, Botucatu, v. 41, n.4, p. 262-269, 2015.

3. Frac. Recommendations for fungicide mixtures. Fungicide Action Committee. http://www.frac.info/docs/default-source/publications/ frac-recommendations-for-fungicide-mixtures/frac-recommendations-forfungicide-mixtures---january-2010.pdf?sfvrsn=4. Acess on December 
$16^{\text {th }}, 2017$.

4. Godoy, C.V.; Seixas, C.D.S.; Soares, R.M.; Marcelino-Guimarães, F. C.; Meyer, M.C.; Costamilan, L.M. Asian soybean rust in Brazil: past, present, and future. Pesquisa Agropecuária Brasileira, Brasília, DF, v.51, n.5, p.407-421, 2016.

5. Jeger, M.J.; Viljanen-Rollinson, S.L.H. The use of the area under the disease-progress curve (AUDPC) to assess quantitative disease resistance in crop cultivars. Theoretical and Applied Genetics, Wien, v. 102, n.1, p. 32-40, 2001.

6. Klosowski, A.; DeMio, L.L.M.; Miessner, S.; Ronaldo Rodrigues, R.; Stammler, G. Detection of the F129L mutation in the cytochrome $b$ gene in Phakopsora pachyrhizi. Pest Managemment Science, Hoboken, v. 72, p. 1211-1215, 2016.

7. Morel, W. Roya de la soja. Comunicado técnico - Reporte oficial. Serie Fitopatológica no.1 - Junho de 2001. Ministerio de Agricultura y Ganaderia. Subsecretaria de Agricultura. Dirección de Investigación Agrícola. Centro de Investigación Agrícola (CRIA) Capitán Miranda, Itapúa, Paraguay.

8. Reis, E. M.; Deuner, E.; Zanatta, M. In vivo sensitivity of Phakopsora pachyrhizi to DMI and QoI fungicides. Summa Phytopathologica, Botucatu, v.41, n.1, p.21-24, 2015

9. Reis, E.M.; Reis, Andrea, C.; Zanatta, M.; Silva, L.H.C.P. da.; Siqueri, F.V..; Silva, J.R.C. Evolução da redução da sensibilidade de Phakopsora pachyrhizi a fungicidas e estratégia para recuperar a eficiência de controle. 3. Ed., rev. e atual. Passo Fundo: Berthier, 2017. 104 p.

10. Reis, E.M.; Zanatta, M.; Reis, A.C. Relationship between soybean plants defoliation and Asian soybean rust severity. Summa Phytopathologica, Botucatu, 2018a (in press).

11. Reis, E.M.; Zanatta, M.; Reis, A.C. Eficiência do controle de uma doença para igualar ao custo da aplicação terrestre de fungicida. Um exemplo de cálculo com a ferrugem da soja. Summa Phytopathologica, Botucatu, Carta ao Editor, 2018b (in press).

12. Reis, E.M..; Zanatta, M; Reis, A.C; Siva, L.H.C.P. Asian soybean rust control efficacy calculated with AUDPC and with final severity data. Summa Phytopathologica, Botucatu, 2018 (in press)

13. Reunião de pesquisa de soja da região sul (41.: 2016 : Passo Fundo, RS) Ata e resumos [recurso eletrônico] / editores técnicos, José Roberto Salvadori, Benami Bacaltchuk. - Passo Fundo: Ed. Universidade de Passo Fundo, 2016. 6.280Kb; PDF Modo de acesso: < http://www.rpspassofundo.com. $\mathrm{br} /$ index.html $>12$. Access on January, $6^{\text {th }}, 2017$.

14. Schmitz, H. K.; Medeiros, C. A.; Craig, I. R.; Stammler, G. Sensitivity of Phakopsora pachyrhizi towards quinone-outside-inhibitors and demethylation- inhibitors, and corresponding resistance mechanisms. Pest Management Science, Hoboken, v.70, p.378-388, 2014.

15. Silva, L. H. C. P.; Campos, H. D.; Silva, J. R. C.; Ribeiro, G. C.; Rocha, R. R.; Moraes, D. G. Eficácia reduzida de triazóis no controle da ferruE gem asiática. Fitopatologia Brasileira, Lavras, MG., v. 33, p.228. 2008 (Suplemento).

16. Sydow H; Sydow P. Beitrag zur Kenntnis der parasitischen Pilze der Insel Formosa. Annales Mycologici, Berlin, v. 12, p. 105-112. 1914. 